\title{
THE ROLE OF LOCAL AND LANDSCAPE LEVEL FACTORS IN DETERMINING BUMBLEBEE ABUNDANCE AND RICHNESS*
}

\author{
Miklós Sárospataki ${ }^{1 *}$, Réka Bakos ${ }^{1}$, András Horváth ${ }^{2}$, Dóra Neidert ${ }^{3}$ \\ Vivien Horváth ${ }^{1,3}$, Dóra VASKor ${ }^{1}$, Éva Szita ${ }^{3}$ and Ferenc SAMU ${ }^{3}$ \\ ${ }^{1}$ Department of Zoology and Animal Ecology, Faculty of Agricultural and Environmental \\ Sciences, Szent István University, H-2100 Gödöllö, Páter K. u. 1, Hungary \\ ${ }^{2}$ Institute of Botany, Centre for Ecological Research, Hungarian Academy of Sciences \\ H-2163 Vácrátót, Alkotmány út 2-4, Hungary \\ ${ }^{3}$ Plant Protection Institute, Centre for Agricultural Research, Hungarian Academy of Sciences \\ H-1022 Budapest, Herman Ottó út 15, Hungary \\ *Corresponding author: sarospataki.miklos@mkk.szie.hu
}

Wild bees are important contributors to the pollination ecosystem service, but they are especially vulnerable to agricultural intensification which causes the loss and fragmentation of natural habitats. We monitored bumblebee populations (Bombus spp.) in 14 grassland patches incorporated into the agricultural habitat mosaic in the Mezöföld region, Hungary. We asked how bumblebee populations were affected by local vegetation quality and the presence of various landscape elements, including fields in agri-environmental schemes, at various spatial scales. A stratified analysis revealed that vegetation quality, especially the lack of weeds, was the most important local factor that positively affected both bumblebee abundance and species number. We found no significant landscape scale effects between 50-250 m. Between 500-1000 m grassland area in the landscape had consistently significant positive effect on species richness. At the $2 \mathrm{~km}$ scale the extent of arable fields had a negative impact on both abundance and richness. A higher percentage area of arable fields in the landscape participating in agri-environmental schemes had no positive effect on bumblebee abundance or species richness. Considering all local and landscape effects and their possible interactions, model selection and variance partitioning revealed that local factors were the most important determinants of bumblebee richness and abundance. Local and landscape factors had high shared variance but did not interact with each other. The present study indicated that small scale landscape composition had the lowest importance, but larger scale landscape composition was significant, most likely because bumblebees can forage far from their nests. If we are able to provide good quality grassland patches incorporated into the agricultural habitat mosaic, then we can build on the strong spill over propensity of bumblebees and can expect their contribution to the pollination of various crops.

Key words: Bombus, pollination, landscape complexity, grassland, agri-environmental scheme

\section{INTRODUCTION}

From the second part of the 20th century, the intensification of agricultural production became higher than ever before. The intensive agricultural

\footnotetext{
* This paper is dedicated to Prof. László Papp, in honor of his 70th birthday and his outstanding contribution to the fields of dipteran taxonomy and ecology.
} 
management resulted in general biodiversity decline in Europe (DE HeER et al. 2005), leading to a decrease in the level of ecosystem services including pollination (Murray et al. 2009). The landscape change and fragmentation of habitats through agricultural intensification created structurally poor landscapes (Tilman et al. 2001), and these affected the diversity and abundance of pollinators, especially wild bees (Biesmeijer et al. 2006, Goulson et al. 2010, Kremen et al. 2002, Potts et al. 2010, StefFan-Dewenter et al. 2005).

Pollination is an important ecosystem service, provided primarily by bees, which pollinate roughly two-third of the world's crop species (BIEsMEIJER et al. 2006, KLEIN et al. 2007). It has been shown that wild bees are relevant for crop productivity even when honey bees are abundant. Wild insects often pollinate crops more effectively than honey bees, but the two groups of bees also synergistically interact with each other (Brittain et al. 2013, Hoenn et al. 2008). Increasing visitation rate by wild bees overall enhances fruit set (GARIBALDI et al. 2013). However, pollination service showed a very serious decline over the past two decades (KREMEN et al. 2002), with the winter colony loss in honey bees (VAN DER ZeE et al. 2012) leading to a pollination crisis (KeARns et al. 1998, SÁrospataki et al. 2005, Steffan-Dewenter et al. 2005). The decline in wild bees, especially bumblebees, as compared to honeybees, can be regarded as even more serious, because these species are more specialised and their small families cannot buffer against adverse environmental effects (FITZPATRICK et al. 2007). Since 1980, wild bee diversity has declined in most landscapes (Biesmeijer et al. 2006, Nieto et al. 2014). In the present study our study objects were bumblebee assemblages [Bombus (Latreille, 1802) spp., Apidae, Hymenoptera] of grassland patches incorporated in the agricultural habitat mosaic.

The loss of natural and semi-natural habitats can be identified as major drivers of wild bee declines. Particularly the loss of flower-rich, semi-natural landscape elements in farmland, such as field margins, diverse meadows and arable weeds in crops contribute to this process (KENNEDY et al. 2013, TSCHARNTKe et al. 2005). At field level, the increase in the amount of fertilizers applied to arable fields led to a strong decline in species diversity and flower richness within the managed fields (KLeIjn et al. 2009, Kovács-HostyánszKI et al. 2011) and in semi-natural habitats adjacent to fertilized fields (BAKKER \& BERENDSE 1999). Thus, flower rich natural habitats are crucial for the preservation of bumblebee populations at various scales. Insecticide usage was also demonstrated to strongly negatively impact pollinators in and around intensively managed fields (CRESSWELl 2011, RorTAIs et al. 2005). Agri-environmental schemes (AES) are aimed to mitigate the above effects by subsidizing the maintenance of semi-natural landscape elements and also the implementation of less intensive management schemes (Primdahl et al. 2003, SAMU et al. 2010).

We conducted our study in the Mezőföld region, where natural and semi-natural grassland patches of variable vegetation quality are embedded 
in either smaller or larger semi-natural habitat complexes surrounded by arable fields. We have built four basic hypotheses concerning the effect of local and landscape level factors on bumblebee assemblages. (i) We hypothesised that bumblebee abundance and species richness would be affected by local vegetation quality, expecting higher bumblebee abundance and species richness where vegetation species richness is higher and disturbance is lower. (ii) Secondly, we hypothesised that the ratio of various landscape elements, including AES fields, would affect bumblebee populations. We expected that landscapes richer in grasslands could maintain more species and more abundant bumblebee assemblages. (iii) Thirdly, we hypothesised that landscape effects act differently at different ranges, expecting them to be stronger at shorter distances than at longer distances. (iv) Finally, we hypothesised that the overall contribution of local and landscape effects is roughly equal and that they also interact with each other. We expected a positive interaction, resulting in disproportionately more bumblebees if both local and landscape scale factors are favourable.

\section{MATERIAL AND METHODS}

\section{Study area}

Our research was conducted at 14 study sites, each consisting of a grassland patch, in the Mezőföld region, Hungary. The Mezőföld, laying west to the river Danube, is an elevated loess plateau of the average height of $150 \mathrm{~m}$ a.s.l. During ice age valleys eroded into the plateau. Nowadays, due to favourable soil conditions, the plateau is largely arable area, but the valleys can be less effectively managed, and these areas preserved natural, semi-natural habitat complexes, consisting of various grassy areas (pastures, hay meadows, unmanaged grasslands), forested patches, shrubby areas. The studied grassland patches were part of such smaller or larger natural, semi-natural habitat complexes, valleys. We selected grasslands either in larger ( $>50 \mathrm{ha})$, or in small valleys ( $<30 \mathrm{ha})$. The former made the grasslands to be part of a complex landscape situation, while latter meant that the grassland was in a more isolated situation, largely surrounded by arable fields. The studied grasslands were always at a peripheral position within the valleys and had a common border with an adjacent arable field. Bumblebees were collected in the interior of the grassland patches and along the edge to the field separately. Locality data about the sites is given in Table 1 and in Electronic Appendix.

\section{Sampling methods and description of the environment}

Bumblebees were collected using yellow funnel traps (SöDERman et al. 1997) of the design described by Subchev et al. (2004) (VarL type traps, CSALOMON®, Budapest, Hungary). Traps were baited by anethol-eugenol 9:1 lure to attract bumblebees (HAMilton et al. 1970). Killing material in the traps was 70\% ethylene-glycol. The traps were placed at 1.2 $\mathrm{m}$ height, either using natural support (e.g. lower branch of a tree) or wooden poles. Traps were operated for approximately two week periods in June 2011 and 2012 (21 June-5 July 


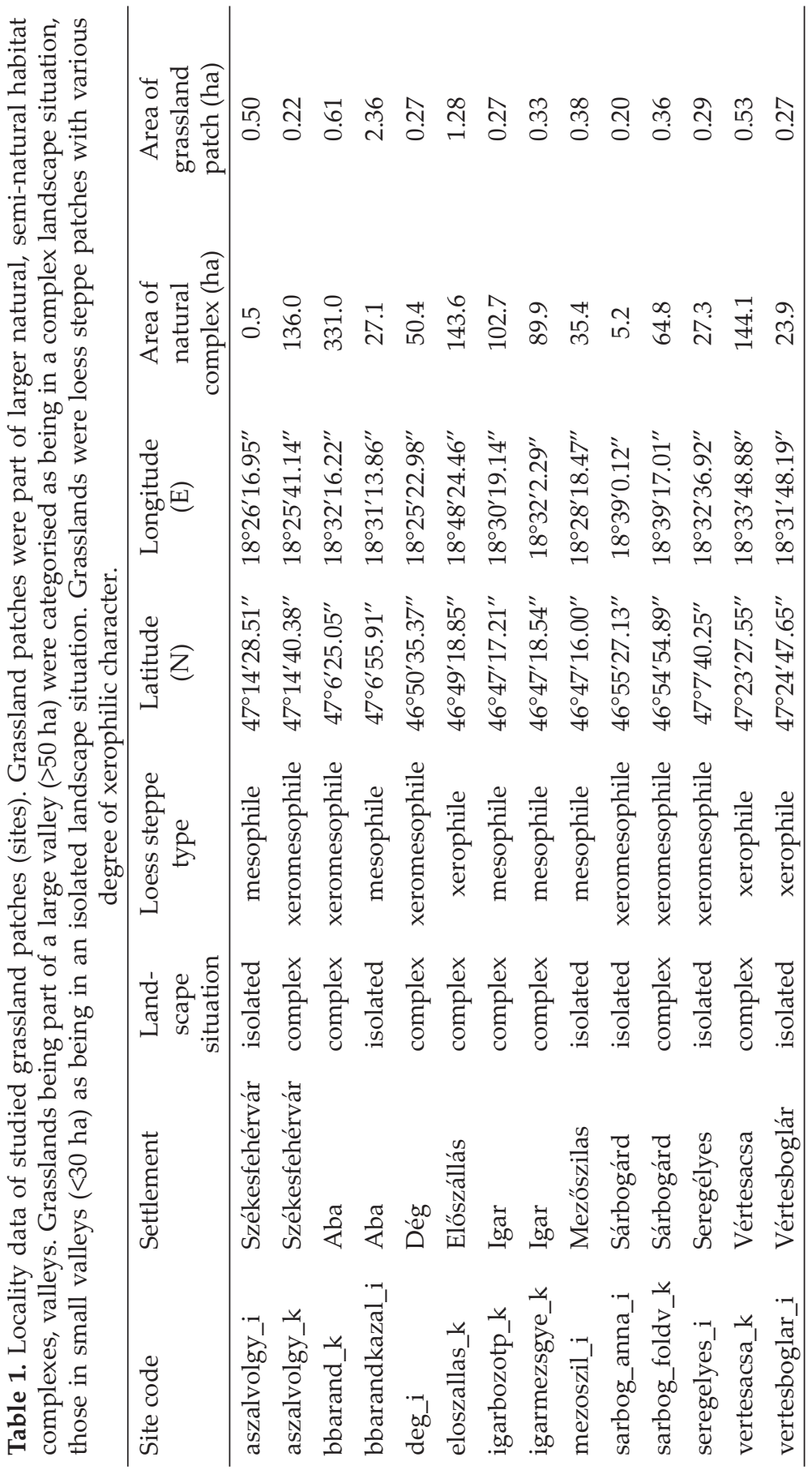


2011; 11-26 June 2012). We placed three traps in a transect with approximately $30 \mathrm{~m}$ between traps. There were two transects within a site, one in the interior of the grassland and one along the edge. In addition to trapping bees, in 2012 on three occasions (on the days of setting and collecting the traps and at an additional date between 18-20 July 2012) we performed 5 minutes long search walks in the vicinity of the traps, amounting to 6 walks per grassland patch per occasion, during which any spotted bumblebee was collected by insect net. All bees collected were conserved in ethanol (70\%). Species identification took place in the laboratory.

Local botanical and relief characteristics of the grasslands both in the interior and at the edge were surveyed. Botanical survey was conducted in $2 \times 2 \mathrm{~m}$ botanical quadrates at six locations at each site, each quadrate being in the few meter vicinity to actual trapping locations, selected as being representative of the vegetation around the trap. All derived botanical variables were originated from species percentage cover estimation within the quadrates. In assessing weediness we considered as weeds the following species: Agropyron repens, Apera spica-venti, Ballota nigra, Calamagrostis epigeios, Cannabis sativa, Carduus acanthoides, Chenopodium spp., Consolida regalis, Echinochloa crus-galli, Erigeron canadensis, Marrubium peregrinum, Sorghum halepense, Urtica dioica.

We also determined the landscape composition by digitising it from aerial photographs within a circle of $2000 \mathrm{~m}$ in radius from the middle of the grassland patch. The percentage areas of three main habitat types (grasslands, wooded areas and arable land) was documented at seven spatial scales, in circles of the following radii (m): 50, 100, 250, $500,750,1000,2000$. At the same scales we also documented the percentage area of arable fields taking part in basic AES programmes (reduced input fields), organic arable fields and orchards taking part in AES programmes.

\section{Statistical analyses}

We conducted statistical analyses to discover local and landscape level factors that affect bumblebee species number and abundance. In spite of our sampling efforts, only relatively low numbers of bumblebees were collected. Therefore, we summarised our data at each study site (keeping edge and interior positions separate), across the two years, the three traps in the transect and collection methods. The two response variables, number of bumblebee species and total number of bumblebee individuals, were $\log _{10}$ transformed to achieve normality. Analyses were performed employing three approaches.

Basic approach. In the first approach we considered landscape situation of the grasslands (levels: complex or isolated) and position within grassland (levels: interior or edge) in a General Linear Mixed Model (GLMM), which included study site as random variable.

Stratified approach. In a second approach a stratified, more detailed, GLMM analysis was applied, to discover the concrete factors that potentially influence bumblebee abundance and richness at local and at landscape level. Similarly to the previous approach, dependency among samples from the same study site was taken into account by including site as random factor into the models. To find the best models we applied backward variable elimination. Starting from a full model at each step we excluded the variable that had the highest $\mathrm{P}$ value, and then assessed whether the reduced model resulted in a drop in BIC (Bayes Information Criterion). We repeated variable elimination until a decrease in BIC was possible. The choice of BIC (as opposed to Akaike's information criterion or F statistics) as a criterion for comparing models is regarded more parsimonious in terms of 
the number of final variables, however, in real-life ecological data this choice rarely makes significant difference (Murtaugh 2009).

To make a stratified analysis, variables were classified according to their scope as being either local, or describing spatiality, or giving landscape level habitat composition. A complete list of variables and their description is given in Table 2. Local variables were separately established for the interior part and the edges of the grassland patches.

During the stratified model selection we first built a model from local variables. Prior to defining the full model, we studied the correlation structure among the local variables, and found that four variables: naturalness, weediness, plant species richness and distur-

Table 2. Description of local, spatial and landscape variables used in the analyses.

\begin{tabular}{|c|c|c|}
\hline type & variable & description \\
\hline \multirow[t]{11}{*}{ local } & xerophile & degree of xerophility: xerophile, xero-mesophile, mesophile \\
\hline & naturalness & naturalness of vegetation, 5 levels \\
\hline & physiognomy & degree of stratification of the vegetation, 4 levels \\
\hline & vegetation height & mean height of vegetation $(\mathrm{cm})$ \\
\hline & grassland cover & $\%$ area covered \\
\hline & shrub dominance & dominance of shrubs, 7 levels \\
\hline & species richness & plant species richness, 8 levels \\
\hline & weediness & cover by weed species, 7 levels \\
\hline & disturbance & intensity of disturbance, e.g. mowing, 3 levels \\
\hline & slope & slope in degrees \\
\hline & southern & degree of southern exposition \\
\hline \multirow[t]{5}{*}{ spatial } & $\mathrm{x}$ & longitude, according to Hungarian coordinate system, EOV \\
\hline & $\mathrm{y}$ & latitude, EOV \\
\hline & $x^{2}$ & $x^{2}$ \\
\hline & $\mathrm{y}^{2}$ & $\mathrm{y}^{2}$ \\
\hline & xy & xy \\
\hline \multirow[t]{6}{*}{$\begin{array}{l}\text { land- } \\
\text { scape }\end{array}$} & arable & $\begin{array}{l}\% \text { area of arable land, within circles of } 50,100,250,500, \\
750,1000 \text { and } 2000 \mathrm{~m} \text { of radii }\end{array}$ \\
\hline & grassland & $\begin{array}{l}\% \text { area of grassland, within circles of } 50,100,250,500,750, \\
1000 \text { and } 2000 \mathrm{~m} \text { of radii }\end{array}$ \\
\hline & wooded & $\begin{array}{l}\% \text { area of wooded areas, within circles of } 50,100,250,500, \\
750,1000 \text { and } 2000 \mathrm{~m} \text { of radii }\end{array}$ \\
\hline & arable AES & $\begin{array}{l}\% \text { area of arable land in AES scheme, within circles of 50, } \\
100,250,500,750,1000 \text { and } 2000 \mathrm{~m} \text { of radii }\end{array}$ \\
\hline & arable organic & $\begin{array}{l}\% \text { area of organic arable land, within circles of } 50,100,250, \\
500,750,1000 \text { and } 2000 \mathrm{~m} \text { of radii }\end{array}$ \\
\hline & orchard AES & $\begin{array}{l}\% \text { area of orchard in AES scheme, within circles of 50, 100, } \\
250,500,750,1000 \text { and } 2000 \mathrm{~m} \text { of radii }\end{array}$ \\
\hline
\end{tabular}


bance were highly correlated (see Appendix 1), constituting the "naturalness variable group". Correlations with the response variables were the highest for weediness, plus this had the most acceptable distribution after logarithm transformation, therefore out of the naturalness variable group we entered only weediness into the full model. Grassland cover was also excluded, because it was $100 \%$ at 13 grasslands and $95 \%$ at one grassland. When the best local model was reached, its significant variables were included in all models in the next stages of the stratified model selection.

In the next stage of the stratified model selection, in order to control for any broad pattern arising from spatiality (e.g. regional gradients), we applied a simple trend-surface analysis. This was done by including $x$, y geographical coordinates up to their quadratic polynomials into the full model (BorCARD et al. 2011) besides any local variables inherited from the previous stage. Applying model selection, if the final model included significant spatial variable, then that was included in the third stage models.

In the third stage of the stratified procedure we included landscape level variables additionally to variables inherited from previous stages. This was done separately for each spatial scale, thus we were able to select a model for each spatial scale at the landscape level. Details, including selected variables, parameter estimates, test statistics and their significance along with model goodness of fit are listed for each model, identified by model number in square brackets, in Appendix 2.

Partitioning approach. In the third approach we wanted to reveal what was the relative contribution of local and landscape variables in shaping bumblebee communities and whether there was any interaction between them. Since we had a high number of variables both at the local and at the landscape level, we ran Principal Component Analyses (PCA) separately on local and landscape level variables. In the former we included all local variables, including all four variables of the naturalness variable group, while in the latter we considered all spatial scales in a single PCA analysis. For both response variables (species richness and abundance) we included the first two PCA axes for the local and for the landscape level PCAs and the interaction term between local PCA axis 1 and landscape level PCA axis 1 and the random term site into the full model (GLMM). To arrive to the final models we applied the above described backward variable elimination model selection procedure. By eliminating either both local PCA variables or both landscape PCA variables or the single interaction term, we have also performed a variation partitioning. In variation partitioning we applied the method of MAC NALLY (1996), whereby the unique proportion of a variable was assessed by the change in $\mathrm{R}^{2}$ when that variable was removed from the full model, overall contribution is assessed by entering only the variable of interest, and shared contribution is derived by subtraction the unique from overall contribution.

Significance is mentioned in the Results if $\mathrm{P}<0.05$, whereas exact $\mathrm{P}$ values are given in Appendix 2. Statistical analyses were carried out using the statistical software JMP version 6.0 (SAS INSTITUTE 2005).

\section{RESULTS}

Over the two years' study at the 14 sites we collected 419 bumblebee individuals, which represented 7 species, with Bombus terrestris (Linnaeus, 1758) accounting for nearly $3 / 4$ of all individuals. The list of species and their relative dominance is given in Table 3. 
Table 3. List of bumblebee species caught during the study, indicating their relative dominance $(\%)$.

\begin{tabular}{lc}
\hline Bumblebee species & Dominance (\%) \\
\hline Bombus terrestris (Linnaeus, 1758) & 73.5 \\
Bombus lapidarius (Linnaeus, 1758) & 10.2 \\
Bombus ruderarius (Müller, 1776) & 8.4 \\
Bombus hortorum (Linnaeus, 1761) & 5.8 \\
Bombus sylvarum (Linnaeus, 1761) & 1.3 \\
Bombus pascuorum (Scopoli, 1763) & 0.4 \\
Bombus pratorum (Linnaeus, 1761) & 0.4 \\
\hline
\end{tabular}

Basic approach. Position within grassland significantly affected both bumblebee abundance (Appendix 2 [1]; Fig. 1a) and species number (Appendix 2 [2]; Fig. 1b), as the interior of the grasslands had higher species richness and abundance. However, landscape situation had no significant effect on either
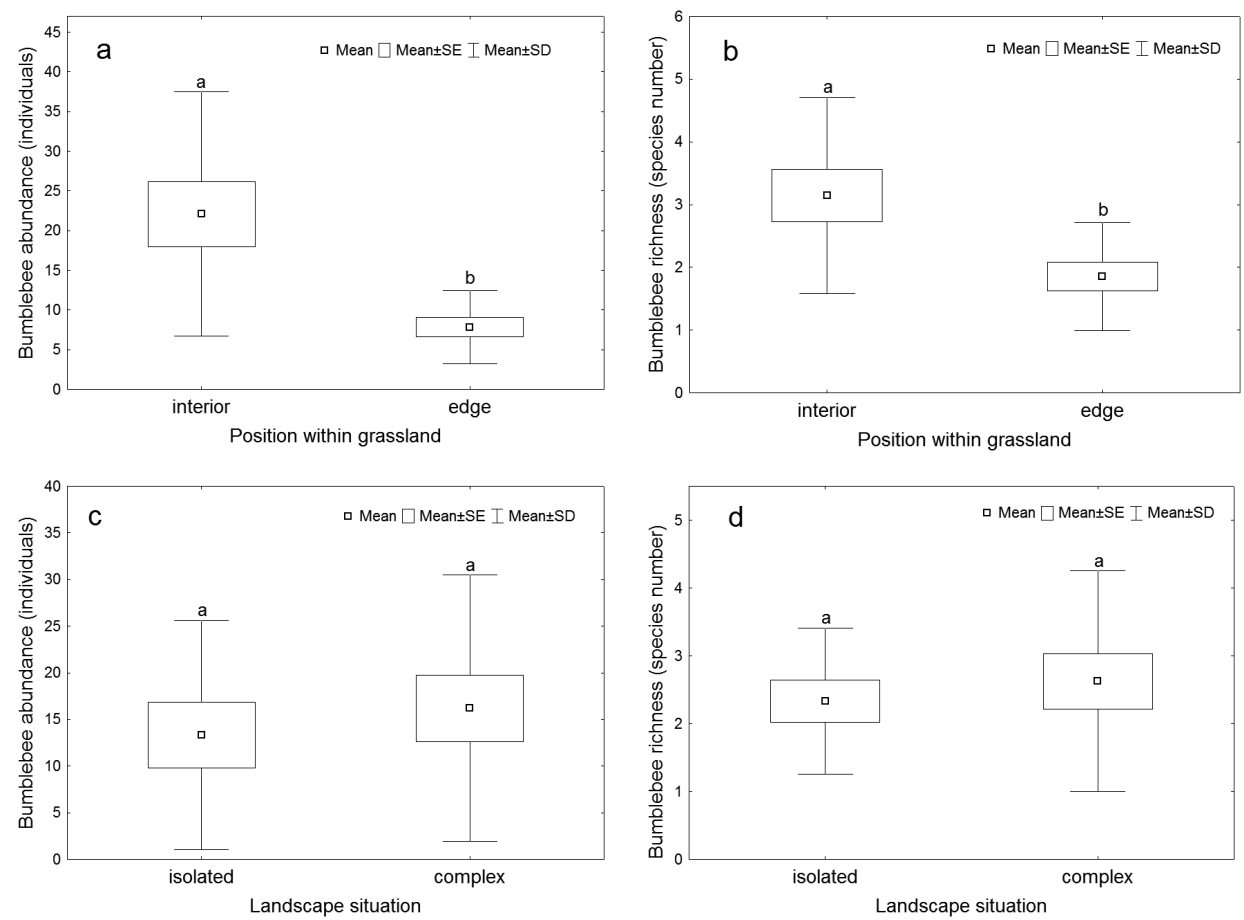

Fig. 1. Mean number $( \pm S E, S D)$ of bumblebee individuals according to within grassland position (a); landscape situation (c); and mean number of species ( \pm SE, SD) according to within grassland position (b); and landscape situation (d). 
bumblebee numbers or species richness, in complex landscape situation there was a trend of higher values (Appendix 2 [1-2]; Fig. 1c-d). In both abundance and species number models the random factor of site represented a very high percentage of variance $(66.5 \%$ and $82.1 \%$, respectively).

Stratified approach. We ran a stratified analysis including more detailed variables both about local vegetation and relief, about spatiality and about landscape composition, keeping site as random factor in each model. At local scale both abundance and species numbers were highly significantly negatively influenced by weediness (Appendix 2 [3-4]), which can also be viewed as a negative measure of naturalness $(\mathrm{r}=-0.87)$ and plant species richness $(\mathrm{r}=$ -0.89 ). Edges had on average twice as high weediness score than interiors ( $\mathrm{F}=$ 66.31 ; d.f. $=1,26 ; \mathrm{P}<0.0001)$. The degree of southern exposure had a marginal effect on the number of bumblebees (Appendix 2 [3]). We kept weediness for further levels of modelling. Analysing spatiality for the response variables (Appendix 2 [5-6]) we found the significance of $\mathrm{y}^{2}$ term for species richness, which was included in all further models.

Landscape level analysis was conducted separately for increasing spatial scales. Bumblebee abundance was not affected significantly by landscape variables at small scales (Appendix 2 [7-12]), although wooded habitats appeared at medium scales as positive, albeit not significant factors. At the 2 $\mathrm{km}$ scale the amount of grasslands in the landscape was positively correlated with bumblebee abundance and the area of organic arable fields had a negative effect (Appendix 2 [13]). Somewhat similarly, species richness was not influenced significantly by landscape level factors at smaller scales. As the scale increased the area of arable fields had a growing negative impact, reaching marginally significant level at the $250 \mathrm{~m}$ radius (Appendix 2 [14-16]). At larger scales grassland area in the landscape had consistently significant positive effect between 500-1000 m (Appendix 2 [17-19]). At the $2 \mathrm{~km}$ scale arable and organic arable fields had negative effect on species richness (Appendix 2 [20]).

Partitioning approach. We applied PCA to both local and landscape level factors. The first axes of the PCA on the local variables explained $51.4 \%$ of the variance, the second axis representing an additional $17.8 \%$ (axis 1: Eigenvalue $=4.62, \chi^{2}=190.14$, d.f. $=44, \mathrm{P}<0.001$; axis 2 : Eigenvalue $=1.6, \chi^{2}=101.22$, d.f. $=35, \mathrm{P}<0.001)$. The first axes of the PCA on the landscape variables explained $48.3 \%$ of the variance, the second axis representing an additional $4.1 \%$ (axis 1: Eigenvalue $=10.15, \chi^{2}=4286$, d.f. $=230, \mathrm{P}<0.001$; axis 2: Eigenvalue $=$ $4.06, \chi^{2}=4019$, d.f. $=209, \mathrm{P}<0.001$ ). Especially the first axes in both cases, explained a considerable amount of variation in the data and revealed associations between the variables (Fig. 2). To assess the significance of interaction between local and landscape level factors, we have built GLMM models both for species richness and abundance, including the first two PCA axes for the 
Table 4. $R^{2}$ values in the variance partitioning of abundance and species richness representing the unique, overall and shared contributions of local landscape variables. The full model contained local PCA axes 1 and 2 (together "Local"), landscape PCA axes 1 and 2 (together "Landscape") and the interaction term between local and landscape PCA axes 1 ("Local $\times$ Landscape").

\begin{tabular}{lcc}
\hline & $\log _{10}(\mathrm{~N})$ & $\log _{10}(\mathrm{~S})$ \\
\hline Total variance & 1.000 & 1.000 \\
Full model & 0.780 & 0.830 \\
Local × Landscape unique & 0.008 & 0.010 \\
Local overall & 0.778 & 0.818 \\
Local unique & 0.250 & 0.266 \\
Landscape overall & 0.538 & 0.554 \\
Landscape unique & 0.010 & 0.002 \\
Local-Landscape shared & 0.528 & 0.552 \\
\hline
\end{tabular}

local and landscape level factors and the interaction term between the first axes. The final models (Appendix 2 [21-22]) included only the local variables PCA axis 1, and did not include the interaction term, which dropped out, as not being significant.

Variance partitioning shed light on the background of the above findings. Similarly for both richness and abundance, the unique contribution of local variables was much higher, while the unique contribution of landscape variables was negligible, such as that of the interaction term (Table 4). However, if we consider the overall effects, then the contributions are closer together (Table 4). The reason for the discrepancy between overall and unique variance
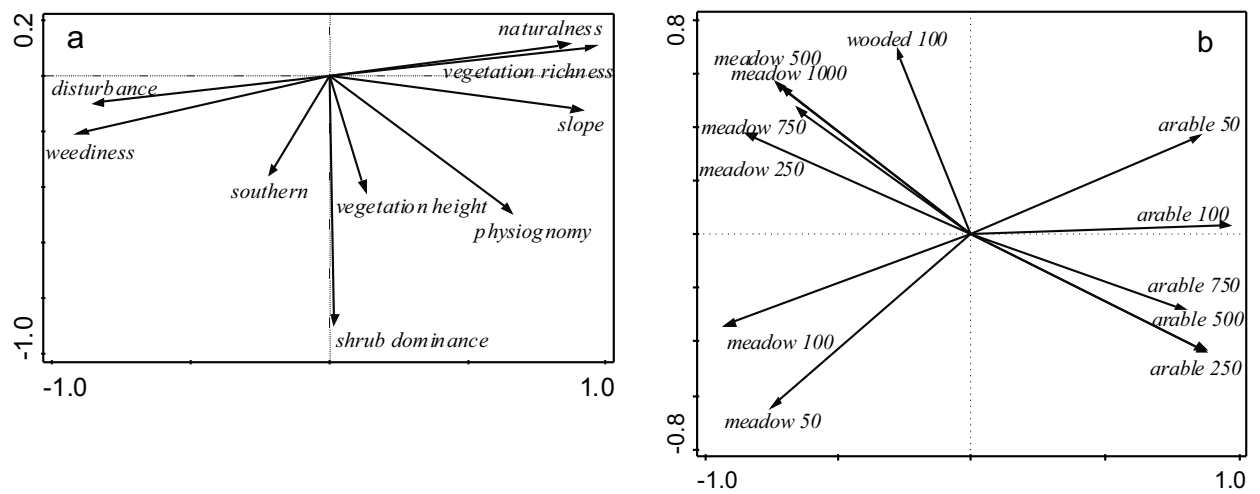

Fig. 2. Principal Component Analysis ordination plots of (a) local and (b) influential landscape scale variables. 
contribution lies in the high amount of variance explained together (approximately $50 \%$ ) by local and landscape effects (Table 4).

\section{DISCUSSION}

Our results showed that overall both local and landscape level factors affected bumblebee numbers and species richness in the studied grassland patches. Grassland interior was far more preferable for the bees than field edges neighbouring agricultural fields. The diameter of the studied grassland patches was in the 100-200 $\mathrm{m}$ diameter range, which is well within the foraging distance of bumblebees (KNight et al. 2005, Osborne et al. 2008). Thus, the abundance and richness differences found clearly mean that bee distribution and not population sizes were affected. That is, we found more bees in the interior, because bees preferred to forage there. It has been demonstrated in other studies that the spatial distribution and quality of resources affected the duration of foraging trips of bumblebees (WestPHAL et al. 2006), because patch residence time is adjusted to patch profitability (LeFEBVRe et al. 2007).

While we found difference between grassland edges and interiors, in our basic approach of analysis landscape situation had no significant effect on the bumblebee populations. Even though, there was a noticeable trend that in grasslands being part of larger valleys (natural, semi-natural habitat complex) there was higher abundance and species richness. Thus, primary analysis gave indication that both local and landscape level factors may play a role in bumblebee distribution, but much of the variance was represented by the random factor "site".

To explain in detail the high variance absorbed by site identity, we applied a stratified analysis including local and landscape level variables. The most important factor affecting local distribution of bumblebees was weediness. This variable was in connection with position within grassland patch, because edges were significantly more weedy. Since weediness was in negative correlation with naturalness and plant species richness, it also meant that bumblebees preferred more diverse parts of the grassland patch, which is in agreement with direct observations in foraging studies (LeFEBvRE et al. 2007, Westphal et al. 2006). We found no direct significant relationship between variables describing grassland vegetation structure (vegetation height, stratification, amount of bushes), whereas CARvell (2002) found that apart from plant species richness vegetation structure and height also had a significant effect on the species richness and foraging activity of bumblebees. Since our grasslands represented the same loess steppe type, it is possible that, apart from weediness and plant diversity, basic vegetation structure was not varied enough to make noticeable effect on bumblebees. 
When analysing the effect of the main habitat types found at different distances around the grassland patches, our most general finding was that closer habitats had less or no influence. This may seem a contra-intuitive finding, however, we think it is explainable by the high foraging ranges of bumblebees. Kovács-HostyánszKi et al. (2011), also in Hungary, found that the percentage of semi-natural habitats in a $500 \mathrm{~m}$ radius did not influence bee species richness and abundance of bumblebees. According to Heard et al. (2007) bumblebee densities were higher locally if the patch was more profitable, but, controlling for that, densities did not vary with patch size, i.e. total forager numbers were proportional to patch area. Thus, if we are well within the foraging range, then neighbouring habitats or habitat extent matter relatively little. Indeed, in an individual level harmonic radar study it was established that bumblebees do not necessarily forage close to their nest, they often visit destinations beyond the nearest available forage (Osborne et al. 1999).

Due to bumblebees' large foraging range, landscape level effects start to matter over $c a 500 \mathrm{~m}$. These insects very effectively utilise resources within $500 \mathrm{~m}$ of colonies, and that can extend to at least $1.5 \mathrm{~km}$, but less than 4 km (Knight et al. 2005, Osborne et al. 2008). From favourable habitats bumblebee populations can spill over at least $1 \mathrm{~km}$ into surrounding farmland (Goulson et al. 2010). Bee species richness and bumblebee density correlated most strongly with organic cropping in landscape sectors with $500 \mathrm{~m}$ radius (Holzschun et al. 2008). In the present study we found significant relationship to landscape characteristics for bumblebee abundance only at the $2 \mathrm{~km}$ scale and between $0.5-2 \mathrm{~km}$ for bumblebee richness.

Likewise Diaz-Forero et al. (2012), we also found that the presence of grasslands in the landscape increases bumblebee abundance. We had this effect within a $2 \mathrm{~km}$ radius. At the same radius the amount of organic arable fields had a negative impact, presumably because their area competed with the area of grasslands. Species richness was influenced already at medium scales in our study. At $250 \mathrm{~m}$ arable area had a marginally significant negative impact, from 500-1000 m grasslands had positive effects. Similarly to abundance, at the largest scale of the investigation, at $2 \mathrm{~km}$, the extent of arable fields (including organic fields) had negative effect. This is in agreement with the findings of Prwell et al. (2006), that the richness of the bumblebee assemblage at a $10 \times 10 \mathrm{~km}$ square scale was positively correlated with land use heterogeneity and the proportion of grasslands.

While we were able to reveal the specific factors and their effective range that contributed to the landscape scale effects, the unique contribution of the surrounding landscape was minimal, because much of this effect overlapped with the effect of local scale variables. This is in agreement with a recent synthesis that highlighted the importance of bee-friendly habitats and manage- 
ment practices in the preservation of wild bee populations (Kennedy et al. 2013). In our case this constituted of the naturalness state of the grasslands in overlap with the positive effect of grassland areas at middle-range distances in the landscape.

Our study revealed that in a predominantly agricultural landscape the quality of grassland remnants is important in keeping up wild bee populations. Bumblebees have high dispersal power and they forage far from their nests. This is a very important trait, which lowers the importance of small scale landscape composition, but makes larger scale composition significant. This way a structurally complex landscape may enhance local abundance and diversity in agroecosystems. Organisms with high dispersal abilities appear to have strong influence on biodiversity patterns and ecosystem services, because of their recolonization ability and ability to utilise resources at larger scales (TscharnTKe et al. 2005). Arable fields participating in AES, that were present in the studied landscapes of the concrete study, had no positive effect. However, the significant impact of grassland quality draws the attention to the importance of grassland management, which at the landscape scale is also connected to arable management intensity. If we are able to provide sufficient and good quality grassland patches incorporated into the agricultural habitat mosaic, then we can build on the strong spill over propensity of bumblebees and can expect their contribution to pollination.

Acknowledgements - The authors are grateful to Erika Botos for field and laboratory assistance and to Zoltán Tóth for statistical advice. The project was financed by OTKA grant No. K81971.

\section{REFERENCES}

BAKKer, J. P. \& Berendse, F. (1999) Constraints in the restoration of ecological diversity in grassland and heathland communities. Trends in Ecology \& Evolution 14: 63-68. http:// dx.doi.org/10.1016/s0169-5347(98)01544-4

Biesmeijer, J. C., Roberts, S. P. M., Reemer, M., Ohlemuller, R., Edwards, M., Peeters, T., Schaffers, A. P., Potts, S. G., Kleukers, R., Thomas, C. D., Settele, J. \& Kunin, W. E. (2006) Parallel declines in pollinators and insect-pollinated plants in Britain and the Netherlands. Science 313: 351-354. http://dx.doi.org/10.1126/science.1127863

Borcard, D., Gillet, F. \& Legendre, P. (2011) Numerical ecology with R. Springer, New York, $306 \mathrm{pp}$.

Brittain, C., Williams, N., Kremen, C. \& Klein, A. M. (2013) Synergistic effects of nonApis bees and honey bees for pollination services. Proceedings of the Royal Society BBiological Sciences 280: 20122767. http://dx.doi.org/10.1098/rspb.2012.2767 
Carvell, C. (2002) Habitat use and conservation of bumblebees (Bombus spp.) under different grassland management regimes. Biological Conservation 103: 33-49. http:// dx.doi.org/10.1016/S0006-3207(01)00114-8

Cresswell, J. E. (2011) A meta-analysis of experiments testing the effects of a neonicotinoid insecticide (imidacloprid) on honey bees. Ecotoxicology 20: 149-157. http://dx.doi. org/10.1007/s10646-010-0566-0

de Heer, M., Kapos, V. \& ten Brink, B. J. E. (2005) Biodiversity trends in Europe: development and testing of a species trend indicator for evaluating progress towards the 2010 target. Philosophical Transactions of the Royal Society of London. Series B, Biological Sciences 360: 297-308. http://dx.doi.org/10.1098/rstb.2004.1587

Diaz-Forero, I., Kuusemets, V., Mänd, M., LiıvamäGi, A., KaArt, T. \& Luig, J. (2012) Influence of local and landscape factors on bumblebees in semi-natural meadows: A multiple-scale study in a forested landscape. Journal of Insect Conservation 17: 113-125. http://dx.doi.org/10.1007/s10841-012-9490-3

Fitzpatrick, U., Murray, T. E., Paxton, R. J., Breen, J., Cotton, D., Santorum, V. \& Brown, M. J. F. (2007) Rarity and decline in bumblebees - A test of causes and correlates in the Irish fauna. Biological Conservation 136: 185-194. http://dx.doi.org/10.1016/j.biocon.2006.11.012

Garibaldi, L. A., Steffan-Dewenter, I., Winfree, R., Aizen, M. A., Bommarco, R., Cunningham, S. A., Kremen, C., Carvalheiro, L. G., Harder, L. D., Afik, O., Bartomeus, I., Benjamin, F., Boreux, V., Cariveau, D., Chacoff, N. P., Dudenhöffer, J. H., Freitas, B. M., Ghazoul, J., Greenleaf, S., Hipólito, J., Holzschuh, A., Howlett, B., Isaacs, R., Javorek, S. K., Kennedy, C. M., Krewenka, K. M., Krishnan, S., Mandelik, Y., Mayfield, M. M., Motzke, I., Munyuli, T., Nault, B. A., Otieno, M., Petersen, J., Pisanty, G., Potts, S. G., Rader, R., Ricketts, T. H., Rundlöf, M., Seymour, C. L., Schüepr, C., Szentgyörgyi, H., Taki, H., TscharntKe, T., Vergara, C. H., Viana, B. F., Wanger, T. C., Westphal, C., Williams, N. \& Klein, A. M. (2013) Wild pollinators enhance fruit set of crops regardless of honey bee abundance. Science 339: 1608-1611. http://dx.doi.org/10.1126/science.1230200

Goulson, D., Lepais, O., O'Connor, S., Osborne, J. L., Sanderson, R. A., Cussans, J., Goffe, L. \& Darvill, B. (2010) Effects of land use at a landscape scale on bumblebee nest density and survival. Journal of Applied Ecology 47: 1207-1215. http://dx.doi. org/10.1111/j.1365-2664.2010.01872.x

Hamilton, D. W., Schwartz, P. H. \& Townshend, B. G. (1970) Capture of bumble bees and honey bees in traps baited with lures to attract japanese beetles. Journal of Economic Entomology 63: 1442-1446. http://dx.doi.org/10.1093/jee/63.5.1442

Heard, M. S., Carvell, C., Carreck, N. L., Rothery, P., Osborne, J. L. \& Bourke, A. F. G. (2007) Landscape context not patch size determines bumble-bee density on flower mixtures sown for agri-environment schemes. Biology Letters 3: 638-641. http:// dx.doi.org/10.1098/rsbl.2007.0425

Hoenn, P., Tscharntke, T., Tylianakis, J. M. \& Steffan-Dewenter, I. (2008) Functional group diversity of bee pollinators increases crop yield. Proceedings of the Royal Society B-Biological Sciences 275: 2283-2291. http://dx.doi.org/10.1098/rspb.2008.0405

Holzschum, A., Steffan-Dewenter, I. \& Tscharntke, T. (2008) Agricultural landscapes with organic crops support higher pollinator diversity. Oikos 117: 354-361. http:// dx.doi.org/10.1111/j.2007.0030-1299.16303.x

Kearns, C. A., Inouye, D. W. \& Waser, N. M. (1998) Endangered mutualisms: The conservation of plant-pollinator interactions. Annual Review of Ecology and Systematics 29: 83-112. http://dx.doi.org/10.1146/annurev.ecolsys.29.1.83 
Kennedy, C. M., Lonsdorf, E., Neel, M. C., Williams, N. M., Ricketts, T. H., Winfree, R., Bommarco, R., Brittain, C., Burley, A. L., Cariveau, D., Carvalheiro, L. G., Chacoff, N. P., Cunningham, S. A., Danforth, B. N., Dudenhoeffer, J.-H., Elle, E., Gaines, H. R., Garibaldi, L. A., Gratton, C., Holzschuh, A., Isaacs, R., Javorek, S. K., Jha, S., Klein, A. M., Krewenka, K., Mandelik, Y., Mayfield, M. M., Morandin, L., Neame, L. A., Otieno, M., Park, M., Potts, S. G., Rundlof, M., Saez, A., SteffanDewenter, I., Taki, H., Viana, B. F., Westphal, C., Wilson, J. K., Greenleaf, S. S. \& Kremen, C. (2013) A global quantitative synthesis of local and landscape effects on wild bee pollinators in agroecosystems. Ecology Letters 16: 584-599. http://dx.doi. org/10.1111/ele.12082

Kleijn, D., Kohler, F., Báldi, A., Batáry, P., Concepcion, E. D., Clough, Y., Diaz, M., GAbriel, D., Holzschuh, A., Knop, E., Kovács, A., Marshall, E. J. P., Tscharntke, T. \& Verhulst, J. (2009) On the relationship between farmland biodiversity and land-use intensity in Europe. Proceedings of the Royal Society B-Biological Sciences 276: 903-909. http://dx.doi.org/10.1098/rspb.2008.1509

Klein, A.-M., Vaissière, B. E., Cane, J. H., Steffan-Dewenter, I., Cunningham, S. A., KreMEN, C. \& TscharntKe, T. (2007) Importance of pollinators in changing landscapes for world crops. Proceedings of the Royal Society B 274: 303-313. http://dx.doi.org/10.1098/ rspb.2006.3721

Knight, M. E., Martin, A. P., Bishop, S., Osborne, J. L., Hale, R. J., Sanderson, R. A. \& Goulson, D. (2005) An interspecific comparison of foraging range and nest density of four bumblebee (Bombus) species. Molecular Ecology 14: 1811-1820. http://dx.doi. org/10.1111/j.1365-294X.2005.02540.x

Kovács-Hostyánszki, A., BAtÁry, P. \& BÁLdi, A. (2011) Local and landscape effects on bee communities of Hungarian winter cereal fields. Agricultural and Forest Entomology 13: 59-66. http://dx.doi.org/10.1111/j.1461-9563.2010.00498.x

Kremen, C., Williams, N. M. \& Thorp, R. W. (2002) Crop pollination from native bees at risk from agricultural intensification. Proceedings of the National Academy of Sciences of the United States of America 99: 16812-16816. http://dx.doi.org/10.1073/pnas.262413599

Lefebvre, D., Pierre, J., Outreman, Y. \& Pierre, J. S. (2007) Patch departure rules in bumblebees: evidence of a decremental motivational mechanism. Behavioral Ecology and Sociobiology 61: 1707-1715. http://dx.doi.org/10.1007/s00265-007-0402-6

MacNally, R. (1996) Hierarchical partitioning as an interpretative tool in multivariate inference. Australian Journal of Ecology 21: 224-228. http://dx.doi.org/10.1111/j.1442-9993.1996.tb00602.x

Murray, T. E., Kuhlmann, M. \& Potts, S. G. (2009) Conservation ecology of bees: populations, species and communities. Apidologie 40: 211-236. http://dx.doi.org/10.1051/ apido/2009015

Murtaugh, P. A. (2009) Performance of several variable-selection methods applied to real ecological data. Ecological Letters 12: 1061-8. http://dx.doi.org/10.1111/j.14610248.2009.01361.x

Nieto, A., Roberts, S. P. M., Kemp, J., Rasmont, P., Kuhlmann, M., Criado, M. G., Biesmeijer, J. C., Bogusch, P., Dathe, H. H., Rúa, P. D. L., Meulemeester, T. D., Dehon, M., Dewulf, A., Ortiz-Sánchez, F. J., Lhomme, P., Pauly, A., Potts, S. G., Praz, C., Quaranta, M., Radchenko, V. G., Scheuchl, E., Smit, J., Straka, J., Terzo, M., Tomoziı, B., Window, J. \& Michez, D. (2014) European Red List of bees. Publications Office of the European Union, Luxemburg. http://dx.doi.org/10.2779/77003

Osborne, J. L., Clark, S. J., Morris, R. J., Williams, I. H., Riley, J. R., Smith, A. D., ReyNOLDS, D. R. \& EDwARDs, A. S. (1999) A landscape-scale study of bumblebee foraging 
range and constancy, using harmonic radar. Journal of Applied Ecology 36: 519-533. http://dx.doi.org/10.1046/j.1365-2664.1999.00428.x

Osborne, J. L., Martin, A. P., Carreck, N. L., Swain, J. L., Knight, M. E., Goulson, D., Hale, R. J. \& SANDERson, R. A. (2008) Bumblebee flight distances in relation to the forage landscape. Journal of Animal Ecology 77: 406-415. http://dx.doi.org/10.1111/j.13652656.2007.01333.x

Potts, S. G., Biesmeijer, J. C., Kremen, C., Neumann, P., Schweiger, O. \& Kunin, W. E. (2010) Global pollinator declines: Trends, impacts and drivers. Trends in Ecology and Evolution 25: 345-353. http://dx.doi.org/10.1016/j.tree.2010.01.007

Primdahl, J., Peco, B., Schramek, J., Andersen, E. \& Onate, J. J. (2003) Environmental effects of agri-environmental schemes in Western Europe. Journal of Environmental Management 67: 129-138. http://dx.doi.org/10.1016/s0301-4797(02)00192-5

Pywell, R. F., Warman, E. A., Hulmes, L., Hulmes, S., Nuttall, P., Sparks, T. H., CritchLEY, C. N. R. \& SHerwood, A. (2006) Effectiveness of new agri-environment schemes in providing foraging resources for bumblebees in intensively farmed landscapes. Biological Conservation 129: 192-206. http://dx.doi.org/10.1016/j.biocon.2005.10.034

Rortais, A., Arnold, G., Halm, M. P. \& Touffet-Briens, F. (2005) Modes of honeybees exposure to systemic insecticides: estimated amounts of contaminated pollen and nectar consumed by different categories of bees. Apidologie 36: 71-83. http://dx.doi. org/10.1051/apido:2004071

Samu, F., Neidert, D., Szita, É., Fetykó, K., Вотta-Dukát, Z. \& Horváth, A. (2010) The role of 'low-input' agri-environmental schemes in the enhancement of functional biodiversity of Hungarian arable fields. IOBC/WPRS Bulletin 56: 105-108.

SAS Institute (2005) JMP Statistics and Graphics Guide, Release 6, SAS Institute Inc., Cary, NC, USA.

SÁrospataki, M., Novák, J. \& Molnár, V. (2005) Assessing the threatened status of bumble bee species (Hymenoptera: Apidae) in Hungary, Central Europe. Biodiversity and Conservation 14: 2437-2446. http://dx.doi.org/10.1007/s10531-004-0152-y

Söderman, G., Leionen, R. \& Lundsten, K. E. (1997) Monitoring bumblebees and other pollinator insects. Finnish Environmental Institute, Helsinki, 43 pp.

Steffan-Dewenter, I., Potts, S. G. \& Packer, L. (2005) Pollinator diversity and crop pollination services are at risk. Trends in Ecology and Evolution 20: 651-653. http://dx.doi. org/10.1016/j.tree.2005.09.004

Subchev, M., Toshova, T., Tóth, M., Voigt, E., Mikulás, J. \& Francke, W. (2004) Catches of vine bud moth Theresimima ampellophaga (Lep., Zygaenidae: Procridinae) males in pheromone traps: effect of the purity and age of baits, design, colour and height of the traps, and daily sexual activity of males. Journal of Applied Entomology 128: 44-50. http://dx.doi.org/10.1046/j.1439-0418.2003.00805.x

Tilman, D., Fargione, J., Wolff, B., D'Antonio, C., Dobson, A., Howarth, R., Schindler, D., Schlesinger, W. H., Simberloff, D. \& Swackhamer, D. (2001) Forecasting agriculturally driven global environmental change. Science 292: 281-284. http://dx.doi. org/10.1126/science.1057544

Tscharntke, T., Klein, A. M., Kruess, A., Steffan-Dewenter, I. \& Thies, C. (2005) Landscape perspectives on agricultural intensification and biodiversity - ecosystem service management. Ecology Letters 8: 857-874. http://dx.doi.org/10.1111/j.14610248.2005.00782.x

van der Zee, R., Pisa, L., Andonov, S., Brodschneider, R., Charriere, J. D., Chlebo, R., Coffey, M. F., Crailsheim, K., Dahle, B., Gajda, A., Gray, A., Drazic, M. M., Higes, 
M., Kauko, L., Kence, A., Kence, M., Kezic, N., Kiprijanovska, H., Kralj, J., Kristiansen, P., Hernandez, R. M., Mutinelli, F., Nguyen, B. K., Otten, C., Ozkirim, A., Pernal, S. F., Peterson, M., Ramsay, G., Santrac, V., Soroker, V., Topolska, G., Uzunov, A., Vejsnaes, F., Wei, S. \& Wilkins, S. (2012) Managed honey bee colony losses in Canada, China, Europe, Israel and Turkey, for the winters of 2008-9 and 2009-10. Journal of Apicultural Research 51: 91-114. http://dx.doi.org/10.3896/ibra.1.51.1.12

Westphal, C., Steffan-Dewenter, I. \& Tscharntke, T. (2006) Foraging trip duration of bumblebees in relation to landscape-wide resource availability. Ecological Entomology 31: 389-394. http://dx.doi.org/10.1111/j.1365-2311.2006.00801.x

Received March 23, 2015, accepted September 20, 2015, published October 6, 2016

Electronic Appendix. Polygons of the study sites using the site codes of Table 1. Google kml file format. 


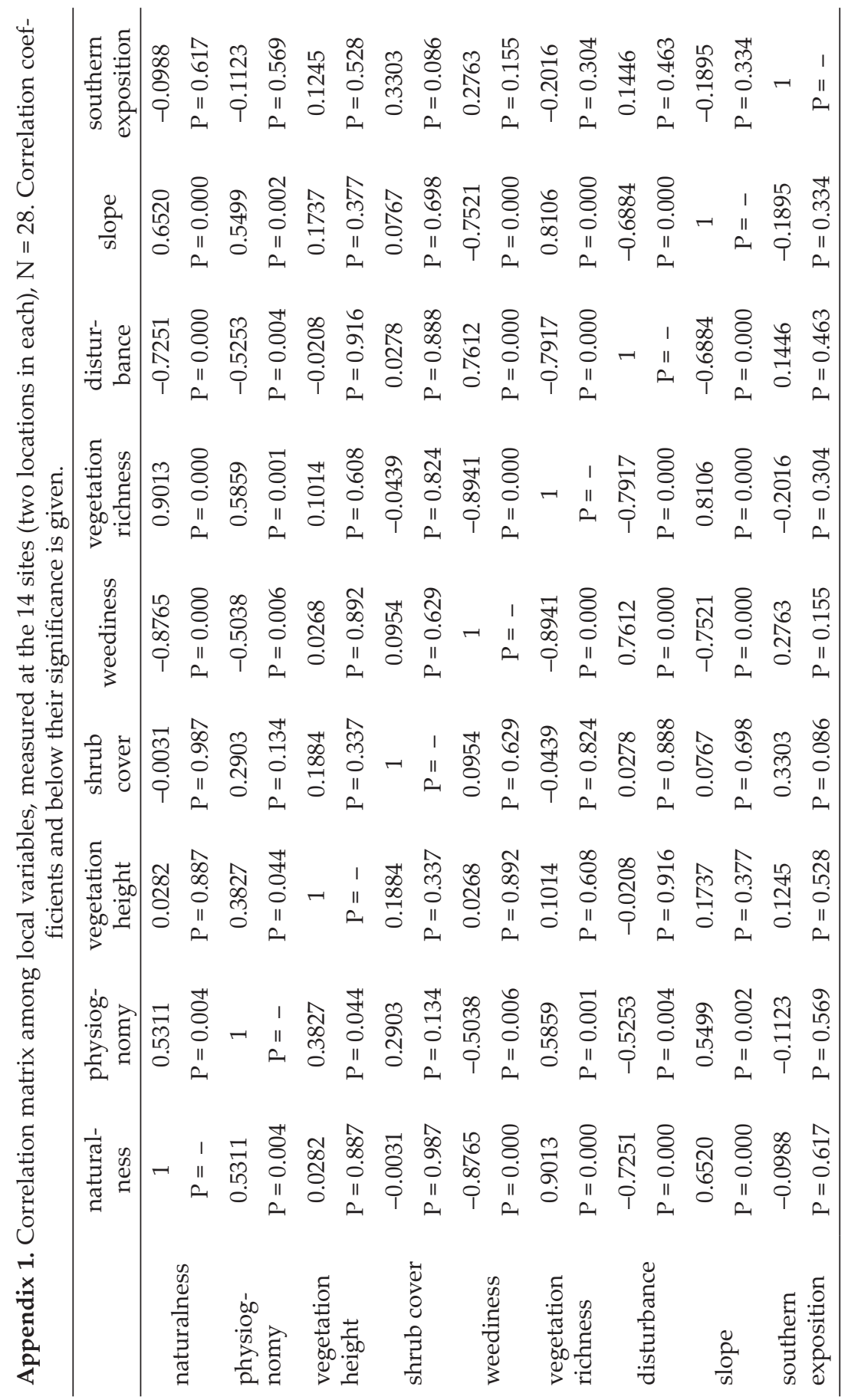




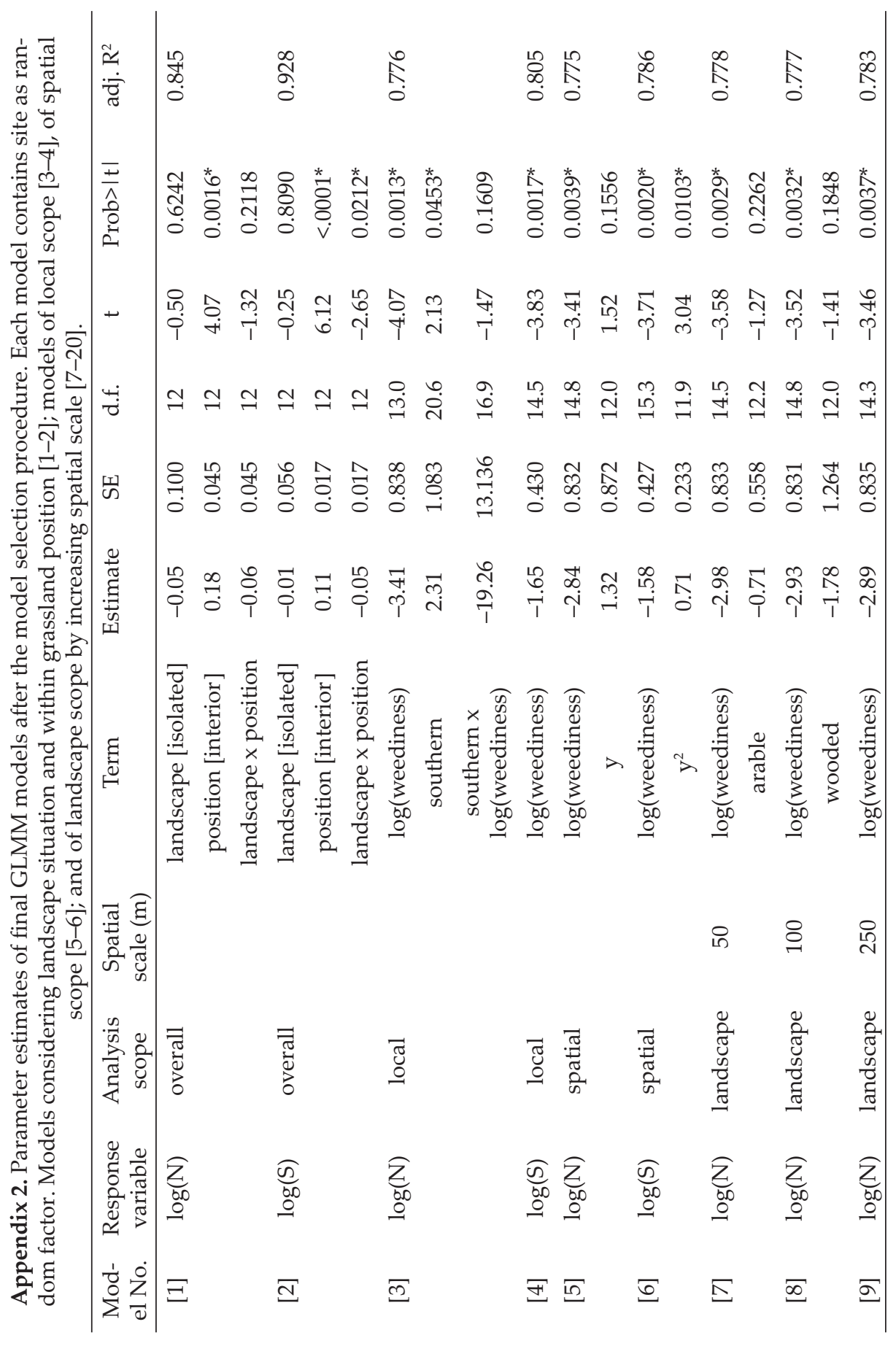




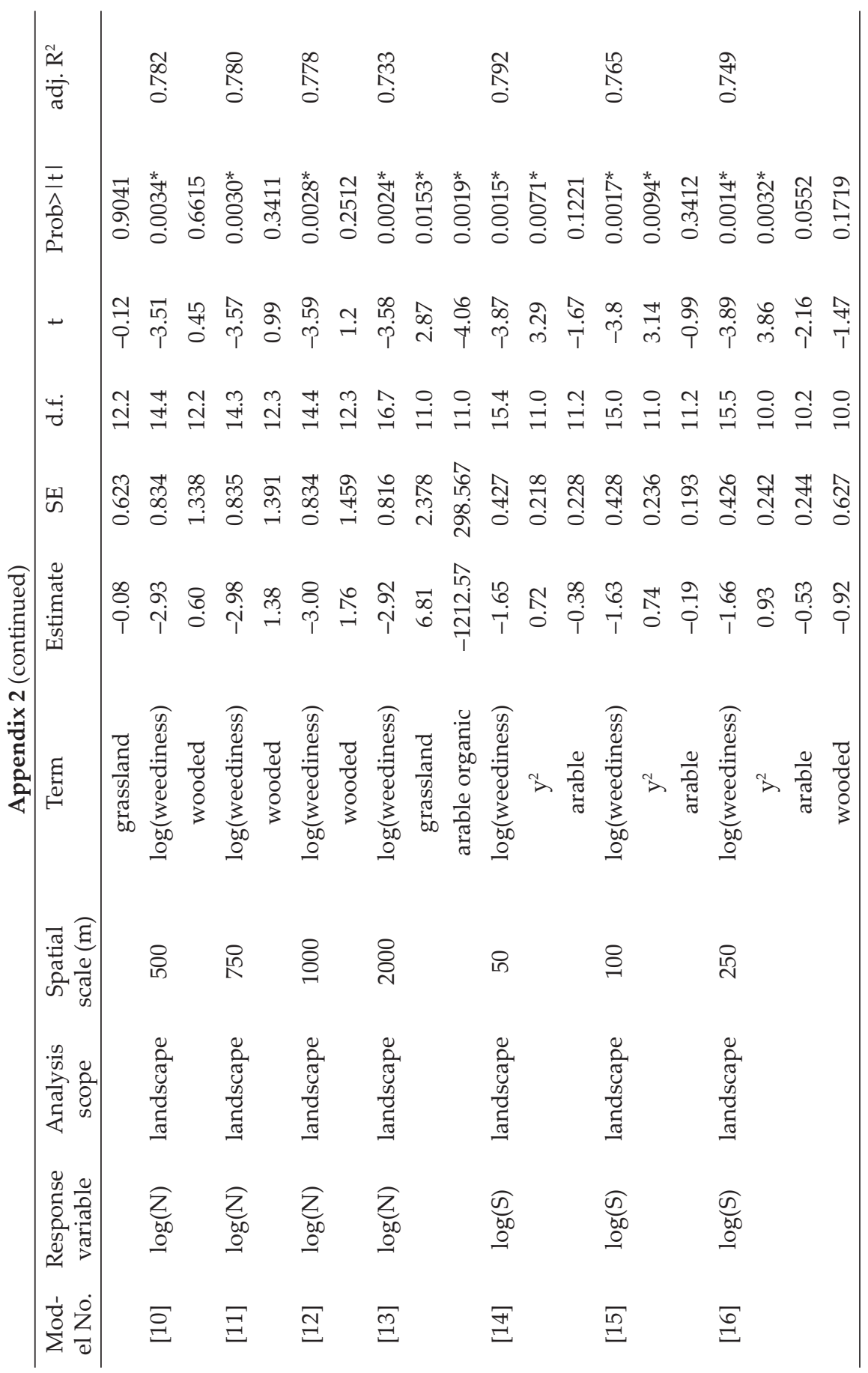




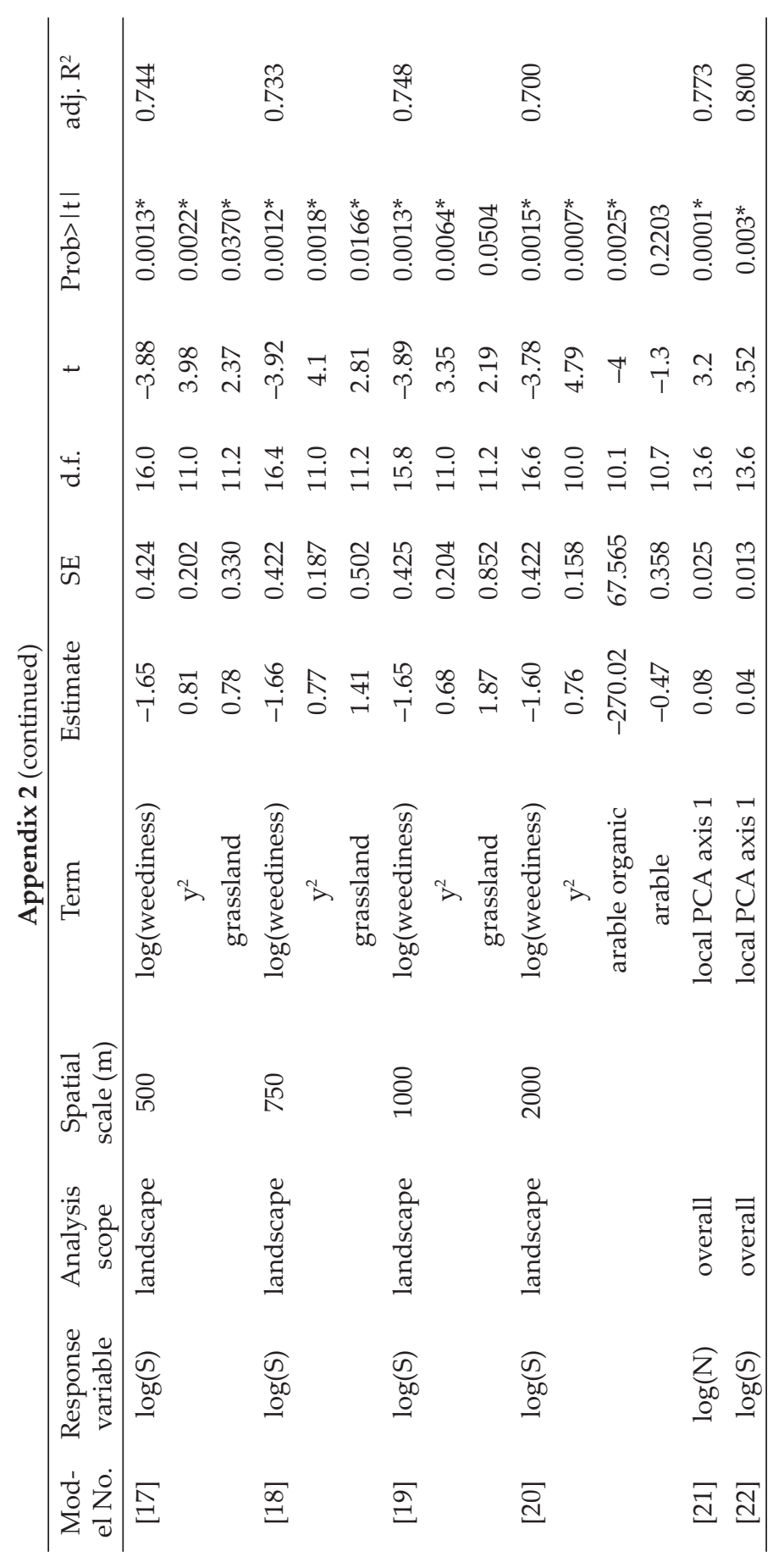

